\title{
Editorial
}

Journal of Innate

Immunity

\section{Innate Immune Mechanisms with a Focus on Small-Molecule Microbe-Host Cross Talk}

\author{
Ute Römling \\ Department of Microbiology, Tumor and Cell Biology, Karolinska Institutet, Stockholm, Sweden
}

"Life would not exist with macromolecules alone" [1]. This thematic issue of the Journal of Innate Immunity takes up a slightly different angle and zooms in on the microbes describing their mutual interactions with the innate immune system via small molecules.

Most of the articles focus or touch upon the bacterial multicellular lifestyle called biofilm. This is maybe not surprising as these microbial populations embedded in a self-produced extracellular matrix adherent to each other and/or to a surface or interfaces [2] have developed intricate tolerance mechanisms against the actions of the immune system and most conventional antimicrobial therapies, which enables biofilm-forming bacteria to associate with $80 \%$ of human infections $[3,4]$. However, fully competent eukaryotic organisms respond with sophisticated defense mechanisms against microbial biofilms [5]. For example, antimicrobial peptides can specifically tackle biofilm bacteria at subinhibitory concentration $[6,7]$. These features of antimicrobial peptides are exploited for novel anti-biofilm therapies as described by Dostert et al. [8] in this issue.

The free radical NO is another innate immune component with a broad concentration-dependent activity against microbes ranging from a signaling molecule-like anti-biofilm to a bactericidal activity $[9,10]$. Williams and Boon [11] describe the anti-biofilm molecular mechanisms of action to be surprisingly convergent in different

\begin{tabular}{ll}
\hline KARGER & ( 2019 The Author(s) \\
Published by S. Karger AG, Basel & Karger \\
E-Mail karger@karger.com & This article is licensed under the Creative Commons Attribution- \\
www.karger.com/jin & $\begin{array}{l}\text { NonCommercial-NoDerivatives 4.0 International License (CC BY- } \\
\text { NC-ND) (http://www.karger.com/Services/OpenAccessLicense). } \\
\text { Usage and distribution for commercial purposes as well as any dis- } \\
\text { tribution of modified material requires written permission. }\end{array}$
\end{tabular}

bacteria with NO being consistently sensed by two types of conserved sensors covalently or noncovalently connected downstream to a quorum sensing and/or second messenger cyclic di-GMP signaling output [12]. Both, extracellular quorum sensing and intracellular cyclic diGMP signaling can be intimately connected to biofilm regulation [12]. Reactive nitrogen and oxygen species are effective bactericidal molecules, but pathogens like gastroenteritis-causing Salmonella typhimurium have also developed effective detoxification and repair defense systems as described by Rhen [13]. Perhaps not surprising, Lesouhaitier et al. [14] report that also nonprofessional innate immune components such as eukaryotic communication molecules interfere with bacterial biofilm formation, physiology, and virulence.

However, the bacteria have evolved the ability to fight innate immune mechanisms. Although primarily recognized as a bacterial derived potent immune stimulatory molecule [15], secreted cyclic di-GMP surprisingly has an anti-innate immune activity preventing lipocalin 2 to sequester iron-scavenging siderophores as discovered by Cui et al. [16]. But microorganisms can not only overcome host siderophore scavenging strategies with their plethora of over 500 recognized siderophores, but counteract a diversity of innate immune mechanisms beyond their anti-scavenging activities as described by Golonka et al. [17]. 
Equally, bacterial quorum-sensing molecules, such as acyl-homoserine lactones of Pseudomonas aeruginosa, initiate an extensive interkingdom cross talk to regulate not only biofilm formation and virulence, but host innate immune components and physiology as described by Turkina and Vikström [18]. Last but not least, innate immune cells such as macrophages respond differently to acute infection-triggering planktonic single microbial cells versus multicellular biofilms, which manipulate the immune cells towards an anti-inflammatory state as reported by Yamada and Kielian [19]. In the same way, Gogoi et al. [20] report that alternatively activated macrophages, which secrete anti-inflammatory molecules, are also the preferred host for the gastrointestinal pathogen S. typhimurium which becomes involved in a complex battle from being restricted in intracellular proliferation to causing host cell death. Small molecules are most abundant. Their functions include serving as nutrients, intermediate metabolites, electron acceptors, external and internal signaling molecules, defense and repair molecules and lifestyle regulators with wider functionality usually not mutually exclusive. Thus, we have certainly just touched upon the complex interactions between bacterial pathogens and the innate immune system involving small molecules [21-25]. With this issue the Journal of Innate Immunity has therefore provided a certainly not fully comprehensive selection of authorized reviews, which hopefully will not only be of interest for the readership, but also prospectively opens up for research articles within this area.

\section{References}

1 Schreiber SL. Small molecules: the missing link in the central dogma. Nat Chem Biol. 2005 Jul;1(2):64-6.

2 Costerton JW, Lewandowski Z, Caldwell DE, Korber DR, Lappin-Scott HM. Microbial biofilms. Annu Rev Microbiol. 1995;49(1):71145.

3 Costerton JW, Stewart PS, Greenberg EP. Bacterial biofilms: a common cause of persistent infections. Science. 1999 May;284(5418): 1318-22.

4 Römling U, Balsalobre C. Biofilm infections, their resilience to therapy and innovative treatment strategies. J Intern Med. 2012 Dec; 272(6):541-61.

5 Gonzalez JF, Hahn MM, Gunn JS: Chronic biofilm-based infections: skewing of the immune response. Pathog Dis 2018;76.

6 Overhage J, Campisano A, Bains M, Torfs EC, Rehm BH, Hancock RE. Human host defense peptide LL-37 prevents bacterial biofilm formation. Infect Immun. 2008 Sep;76(9):417682.

7 Kai-Larsen Y, Lüthje P, Chromek M, Peters V, Wang X, Holm A, et al. Uropathogenic Escherichia coli modulates immune responses and its curli fimbriae interact with the antimicrobial peptide LL-37. PLoS Pathog. 2010 Jul; 6(7):e1001010.

8 Dostert M, Belanger CR, Hancock RE. Design and assessment of anti-biofilm peptides: steps toward clinical application. J Innate Immun. 2018, DOI: $10.1159 / 000491497$.

9 Barraud N, Kelso MJ, Rice SA, Kjelleberg S. Nitric oxide: a key mediator of biofilm dispersal with applications in infectious diseases. Curr Pharm Des. 2015;21(1):31-42.
10 Howlin RP, Cathie K, Hall-Stoodley L, Cornelius V, Duignan C, Allan RN, et al. Low-dose nitric oxide as targeted anti-biofilm adjunctive therapy to treat chronic Pseudomonas aeruginosa infection in cystic fibrosis. Mol Ther. 2017 Sep;25(9):2104-16.

11 Williams DE, Boon EM. Towards understanding the molecular basis of NO-regulated group behaviors in pathogenic bacteria. J Innate Immun. 2018, DOI: 10.1159/000494740.

12 Römling U, Galperin MY, Gomelsky M. Cyclic di-GMP: the first 25 years of a universal bacterial second messenger. Microbiol Mol Biol Rev. 2013 Mar;77(1):1-52.

13 Rhen ME. Salmonella and reactive oxygen species - a love-hate relationship. J Innate Immun. 2019, DOI: 10.1159/000496370.

14 Lesouhaitier O, Clamens T, Rosay T, Desriac F, Louis M, Rodrigues S, et al. Host peptidic hormones affecting bacterial biofilm formation and virulence. J Innate Immun. 2018, DOI: 10.1159/000493926.

15 Karaolis DK, Means TK, Yang D, Takahashi M, Yoshimura T, Muraille E, et al. Bacterial c-di-GMP is an immunostimulatory molecule. J Immunol. 2007 Feb;178(4):2171-81.

16 Cui T, Cang H, Yang B, He ZG. Cyclic dimeric guanosine monophosphate: activation and inhibition of innate immune response. J Innate Immun. 2018, DOI: 10.1159/000492679.

17 Golonka R, Yeoh BS, Vijay-Kumar M. The iron tug-of-war between bacterial siderophores and innate immunity. J Innate Immun. 2018, DOI: 10.1159/000494627.
18 Turkina MV, Vikström E. Bacteriahost crosstalk: sensing of the quorum in the context of Pseudomonas aeruginosa infections. J Innate Immun. 2018, DOI: 10.1159/000494069.

19 Yamada KJ, Kielian T. Biofilm-leukocyte cross-talk: impact on immune polarization and immunometabolism. J Innate Immun. 2018, DOI: $10.1159 / 000492680$

20 Gogoi M, Shreenivas MM, Chakravortty D. Hoodwinking the big-eater to prosper: the Salmonella-macrophage paradigm. J Innate Immun. 2018, DOI: 10.1159/000490953.

21 Sasabe J, Suzuki M: Emerging role of D-amino acid metabolism in the innate defense. Front Microbiol 2018;9:933.

22 Gray MJ, Wholey WY, Jakob U: Bacterial responses to reactive chlorine species. Annu Rev Microbiol 2013;67:141-160.

23 Patel NN, Workman AD, Cohen NA: Role of taste receptors as sentinels of innate immunity in the upper airway. J Pathog 2018; 2018:9541987.

24 Schürmann N, Forrer P, Casse O, Li J, Felmy B, Burgener AV, Ehrenfeuchter N, Hardt WD, Recher M, Hess C, Tschan-Plessl A, Khanna N, Bumann D: Myeloperoxidase targets oxidative host attacks to Salmonella and prevents collateral tissue damage. Nat Microbiol 2017;2:16268.

25 Sigurlasdottir S, Engman J, Eriksson OS, Saroj SD, Zguna N, Lloris-Garcera P, Ilag LL, Jonsson $\mathrm{AB}$ : Host cell-derived lactate functions as an effector molecule in Neisseria meningitidis microcolony dispersal. PLoS Pathog 2017;13: e1006251. 